\title{
Fővárosi detektívtestület az államosítások időszakában 1881-1923.
}

(The Budapest Detective Unit in the Era of Nationalization: 1881-1923)

\section{Absztrakt}

Magyarországon detektívtestület 1885-től 1945-ig müködött. Az első detektívtestületet a Budapesti Magyar Királyi Állami Rendörség kötelékében hozták létre 1885-ben. a testület kiváló müködése nyomán a vidéki nagyvárosok rendőrségeinek a kötelékeiben is felállították a detektívtestületeket. A magyarországi városi rendőrségek 1919. évi államosításakor pedig a fövárosi detektívtestület mintájára a Magyar Királyi Állami Rendőrségben is létrehoztak detektívtestületet, amely 1945-ig müködött. A magyarországi detektívtestületek története két szakaszra bontható, az első időszak 1885-től 1919-ig tartott. Ekkor még a detektívek szervezete sem volt egységes, hiszen a rendőrségek sem voltak azok. A második szakasz 1919-től 1945-ig tartott. Ekkor már az egységes állami rendőrség - 1930-ig Magyar Királyi Állami Rendőrség elnevezéssel, majd ezt követően 1945-ig Magyar Királyi Rendőrség néven múködő szervezet — kebelében egységes detektívtestület müködött.

$$
\text { Kulcsszavak }
$$

Budapesti Magyar Királyi Állami Rendőrség ; Detektívtestület ; a rendőrség államosítása ; Magyar Királyi Állami Rendőrség ; Magyar Királyi Rendőrség

\section{Abstract}

Hungarian law enforcement was nationalized during the Era of the Dual Monarchy. Police training in Hungary became uniform in the wake of this consolidation. Since the police consisted of civilian armed units, they were held to the same qualification standards as those employed in public administration. Thus the public education requirements of the various departments and offices of the police were the same as for those employed in public administration. The public administration education system lay upon a foundation of public education qualifications, differentiated by age and expertise. Those wishing to enroll as commissioned officers were required to pass an entrance exam which varied among the various ministries. Non-commissioned officers, on the other hand, had to successfully complete a course in order to be placed. Additionally physical, psychological and moral standards had to be exhibited in order to be selected into the organization; once in, the same standards were necessary for career advancement. At every level, police training emphasized practicality. Training was not exclusively grounded in cognitive learning but also demanded physical and psychological competency.

Key words:

trial service ; police training system ; study supervisor ; public administration examination ; non-commissioned officer examination

\footnotetext{
"Open Researcher and Contributor ID = Nyílt Kutató és Közremüködő Azonosító (ORCID) : $\underline{\text { https://orcid.org/0000-0003-4166-1625 }}$ Institutional attachements = Szerző intézményi kötődései :

- Bertalan Szemere Scientific Society of History of Hungarian Law Enforcement = Szemere Bertalan Magyar Rendvédelem-történeti Tudományos Társaság

- National University of Publik Service Faculty of Law Enforcement = Nemzeti Közszolgálati Egyetem Rendészettudományi Kar @: szigetvarioszkar@gmail.com

Date of registry = Regisztrálás dátuma : 2019. X. 2.

Date of acceptance $=$ elfogadás dátuma : 2019. XI. 28.
} 
A kiegyezéskor a magyar állam nem vette át az idegen elnyomás kivitelezését is megvalósító, centrális vezetés alatt álló birodalmi rendvédelmi testületek magyarországi szervezeteit. ${ }^{1}$ Ehelyett a municipálisok és a centralisták között megvalósított reformkori közigazgatás elméleti viták nyomán ${ }^{2}$ - a rend védelmét az önkormányzatok kompetenciájába helyezték, ezzel lénygében befejezve azt a folyamatot, amely a neoabszolutizmus enyhébb szakaszában az 1850-es és az 1860-as évek fordulóján már elkezdődött a rendvédelem terén. A dualizmus időszakában — amikor a rend fenntartásának a kompetenciája visszakerült a magyar nemzethez — több szakaszban épült ki a kontinentális típusú magyar rendvédelmi modell. E modellben a rend fenntartása terén a központi magyar államhatalomnak közvetlenül alárendelt rendvédelmi testületek osztoztak az önkormányzati irányítás alá tartozó települési rendőrségekkel a rend fenntartásának a teendőin. ${ }^{3}$ A rend védelemének, mint feladatnak önkormányzati hatáskörbe sorolásáról a köztörvényhatóságok rendezéséről szóló 1870. évi, valamint a községek rendezéséről szóló 1871. évi többször módosított törvények rendelkeztek. ${ }^{4}$ A polgári magyar állam időszakában a központi államhatalom közvetlen alárendeltségében számos rendvédelmi testület müködött, közülük a rendőrség - amely az államosítást megelőzően a nagyobb városokban, majd az államosítást követően valamennyi magyar városra kiterjedően - , továbbá a csendőrség, a pénzügyőrség, a vámőrség, a folyamőrség és a határőrség rendelkezett kisebb-nagyobb, nyomozó munkára specializált szervezeti egységekkel. ${ }^{5}$

Az önkormányzati modell azonban a dualizmus idejében megbukott, ezért a rendvédelem átszervezése elkezdődött. Először a falvakban, majd a városokban indult el a központosítás folyamata, megkezdődött az államosítás. ${ }^{6}$

A fővárosi rendőrségnek kiemelkedő szerepe volt a magyar állami rendőrség létrehozásában, mivel a budapesti rendőrséget már 1872-ben ideiglenesen, majd 1881-ben véglegesen államosították. ${ }^{7}$

Az államosítást elrendelő törvény részletesen szabályozta a rendőrség eljárását, a szervezeti szabályokat, melyekre nézve korábban az úgynevezett sárgakönyv adott gyakorlati útmutatást. ${ }^{8}$

A Budapesti Magyar Királyi Állami Rendőrségről szóló 1881. évi törvényi szabályozás értelmében a fővárosi rendőrség államosítása az 1872-es ideiglenes tervezet beérése, valamint egy országos államosítási folyamat kezdete volt. A törvény értelmében a fövárosi rendőrség feladatát alkotta müködési területén a személy- és vagyonbiztonság megóvása a béke és közrend fenntartása, valamint a büntetőtörvények, rendeletek megszegését akár mulasztásból eredően is megakadályozni, a megzavart rendet helyreállítani, a törvény ellen vétőket felderíteni, beazonosítani és az illetékes hatóság elé állítani vagy velük szemben saját hatáskörben eljárni. A budapesti rendörség továbbá, mint közigazgatási hatóság saját hatáskörében eljárva figyelö, megelőző és felfedező szolgálatot is ellátott. ${ }^{9}$

A megfigyelésre és információgyüjtésre vonatkozó igény egységesen az egyenruhát és a civil öltözéket viselő és nem viselő minden rendőri közegre érvényes volt. A korabeli törvényi szabályozás is a megelőzésre fektette a hangsúlyt, amiket a XXI. század terminológiája felderítő szolgálatok elnevezéssel illett. E tevékenységeket a vizsgált időszakban általában a közigazgatási rendőrség a saját hatáskörben és jogkörben fejtette ki. A fővárosi rendőrség akkor is a törvény és az azzal összhangban kiadott belügyminiszteri rendeletek alapján járt el, amikor közigazgatási hatóságok megkereséseinek tett eleget. A budapesti rendőrségről szóló törvény meghatározta továbbá, hogy büntetendő cselekmények esetében a Budapesti Magyar Királyi Állami Rendőrség előnyomozást hajtson végre, az illetékes ügyészséggel és bírósággal együttmüködve, azok megkereséseit végrehajtva. ${ }^{10}$

Számos korábbi rendőrségi illetékesség alá tartozó ügy fővárosi közigazgatási hatáskörbe került, mint például a piaci rendészet, iparügy. ${ }^{11}$

Láthatjuk tehát, hogy maga a nyomozati tevékenység meghatározásra került, mint feladat, azonban annak végrehajtásával kapcsolatban pontos jogszabályi, rendeleti iránymutatás még nem került megalkotásra. Hiányzott továbbá a kifejezetten nyomozati munkát végrehajtó apparátus, akik, mint ezen tevékenység szakértői müködtek volna. A fővárosi rendőrség a bünesetek felderítésében ebből kifolyólag nem jeleskedett, bünügyi nyilvántartó és jól képzett detektívek híján alulmaradt a kihívásokkal szemben. Akadtak ugyan kitünő nyomozói adottságokkal megáldott rendbiztosok, ${ }^{12}$ akik sikerrel derítettek fel bünügyeket, de ez önmagában egy átfogó eredmény eléréséhez nem volt elegendő. A rendőrség figyelmét lekötötték az utcai mozgalmak zavargásainak kezelése, detektívtanfolyamok nem voltak, az egyenruhás örszemélyzet kapacitása és képzetlensége révén alkalmatlan volt nyomozó munka végzésére. ${ }^{13}$

A rendőrségnek és szolgálati ágainak fejlődése során a kezdeti, úgymond hagyományos rendöri jelleget igénylő feladatok mellett szembe kellett nézni az egyéb új képességeket, tulajdonságokat igénylő kihívásokkal is. Az új feladatok fedett tevékenységet, vagy a rendőri jelleg leplezését, esetleg egyéb nem nyílt információszerzést igényeltek a siker érdekében. E kihívásokat felismerve, ezekre reagálva alakult meg a polgári magyar állam detektív testülete, miután a detektív munka jogszabályi 
környezete is rendezésre került. 1880-ban életbe lépett a Magyar Büntetőtörvénykönyv, amely felváltotta a korábbi „Sárga könyv”-et, ezzel pedig ezen jogterületnek a kor nemzetközi élvonalába tartozó magyar jogi szabályrendszere jött létre. ${ }^{14}$

TÖRÖK János rendör-főkapitány felismerve a rendőrség hiányosságait, a bünügyi helyzetre reagálva 1885. XII. 15-én — TISZA Kálmán miniszterelnök és belügyminiszter utasítására — felállította a detektívosztályt, amely 1886. I. 1-én kezdte meg müködését. ${ }^{15}$

TÖRÖK János budapesti rendőr-fökapitány a fövárosi rendőrség személyi állományának átszervezés előtti kiválóságait megtartva és szorgalmas, becsületes és tehetséges újonnan felvett rendőrökkel gyarapítva a testület létszámát lényegében új rendőrséget hozott létre. A detektívtestület kezdetben 28 fö́t számlált, majd további nyolc detektívet vettek fel, ezzel párhuzamosan pedig a polgári biztosok intézményét megszüntették. A detektívosztály vezetőjévé SPLÉNYI Ödön címzetes kerületi rendőr-kapitányt nevezték ki felügyelöi címmel, ezzel a Budapesti Magyar Királyi Állami Rendörségen belül önálló testületté vált az osztály. TöRÖK János budapesti rendőr-főkapitány 1886-ban kiadott rendeletének értelmében az összes kinevezett detektívet a detektívosztályba sorolták be. Korábban — szolgálati utasítás hiányában — a detektívek a fökapitányság közvetlen vagy a kerületi kapitányságok alárendeltségében látták el feladatukat. ${ }^{16}$

A létszámot folyamatosan bővítették, ami 1911-ben már 190 főre duzzadt, majd év végére további 83 detektív került kinevezésre, 1914-ben pedig elérte a 250 föt. 1919-re a folyamatos bővítéseknek köszönhetően 543 fő detektív látott el szolgálatot. A fövárosi rendőrség detektív testületét 1918 végéig egymást követően 6 detektívfönök vezette. ${ }^{17}$

A történelmi Magyarország $282870 \mathrm{~km}^{2}$ területén 18264533 fönyi lakosság körében nyolc állami (csendőrség - 12000 fö, a nemesi testőrség és a darabont testőrség - 142 fö, pénzügyőrség - 5500 fö, fegyőr testület - 3000 fö, a fövárosi rendőrség, a határrendőrség és a fiumei rendőrség) rendvédelmi testület kötelékében szolgálatot teljesítők létszáma összességében nem érte el a 30000 föt. Emellett 1913-ban 25 törvényhatósági jogú és 111 rendezett tanácsú város is tartott fenn városi rendőrséget, továbbá — mivel a községeknek is joguk volt rendőrség létrehozására — a módosabb falvak a csendőrség felállítása után is müködtettek községi rendőrséget. A községi rendőrségek száma azonban meglehetösen dinamikusan módosult, mivel létük a település financiális helyzetétől és az elöljáróság szemléletmódjától is függött.

Összességében az önkormányzati rendőrségek létszáma mintegy 12000 före tehető, az önkormányzati rendőrségek közül lényegében csak a törvényhatósági jogú városok rendőrségei rendelkeztek csekély létszámú detektívtestülettel. Ezek a detektívtestületek azonban oly jól müködtek, hogy a környezö települések a bonyolult bủnügyek tekintetében általában a legközelebbi nagyváros detektívtestülettel rendelkező rendőrségét kérték fel az ügy felderítésére. Hasonló volt a helyzet a fövárosi és a vidéki nagyvárosok esetében is, mivel a vidéki nagyvárosok rendőrségei által fel nem derített bonyolult ügyek nyomozására általában a fővárosi rendőrséget kérték fel. Az a helyzet alakult ki tehát, hogy a háború első évében a Budapesti Magyar Királyi Állami Rendőrség mintegy 250 főnyi detektívtestülete nyomozott kiváló eredménnyel a fővárosi és részben az agglomeráció büntettei után, illetve az országos büncselekmények elkövetői ellen. Amennyiben figyelmen kívül hagyjuk a nemesi testőrség, a darabont testőrség, a koronaőrség és a fegyőr testület közterületi szolgálatot nem teljesítő személyi állományát akkor megállapítható, hogy a rendőri, csendőri és pénzügyőri összességében mintegy 28000 főnyi személyi állomány egy före kivetített bünfelderítési mutatói kedvezőek voltak. Ezen belül pedig a detektívekre eső bủnfelderítések száma jóval magasabb volt, mint amit a közrendvédelmi állomány elért.

Ez azonban nem azt jelentette, hogy a közrendvédelmi állomány a hivatását rosszul teljesítette volna. Egyszerüen csupán más helyzetben volt a két - mai terminológiával éve — szakszolgálat helyzete. A közrendvédelmi szolgálat fő célját a törvényszegések megelőzése és megakadályozása alkotta. Ebből fakadóan kevesebb bünügy keletkezett. A detektívek fő profilját pedig — bár a bünmegelőzési teendők ellátása is a tevékenységük részét képezte — föként a büncselekmények felderítése alkotta. Ehhez a munkához pedig a megfelelő létszámú detektív biztosítása elengedhetetlen volt. A polgári magyar állam időszakában a magyar rendvédelmi testületek személyi állománya körében a detektívek létszáma dinamikusan gyarapodó tendenciát mutatott.

A detektívszolgálat szervezésében megjelentek a csoportbeosztások, melynek előnye, hogy képességeik alapján szelektálták az embereket és párosították hozzájuk az elvégzendő feladatokat. Tehát a felmerülö feladatot az arra legalkalmasabb detektívek végezhették. Megkezdődött a detektívtestületben a specializáció, amely napjaink nyomozói körében is megfigyelhetö. Természetesen mindenki másban volt tehetséges ezért nem felváltva végezték immár a feladatokat (puhatolás, megfigyelés), a detektívek a nekik leginkább testhezálló tevékenységet folytatták. Ennek a szervezését a csoportvezetők végezték, akikhez 3-4 fö detektív tartozott. A specializáció előnye volt továbbá, hogy bizonyos tevékenységeket 
tökélyre lehetett fejleszteni annak állandó művelése folytán, megteremtve ezzel a sikeres bünüldözés alapjait. $^{18}$

A fö́csoportok tagozódásuk szerint sérülési fócsoport (emberölési ügyek, közlekedési balesetek, személy elleni büncselekménye), intellektuális föcsoport (csalás, sikkasztás, hamisitási ügyek), valamint lopási és betörési föcsoportok voltak. Külön föcsoport foglalkozott az állambiztonsági és sajtóügyekkel. A detektívek müködési körére tekintettel kirendeltségeik lefedték a fövárost és annak kiemelt fontosságú és forgalmú pontjai közelében voltak találhatóak. (Keleti, Déli, Nyugati pályaudvarok, Valutaügynökség stb.) ${ }^{\mathbf{1 9}}$

A rendvédelmi oktatás tekintetében — az 1867-1945 közötti időszakot figyelembe véve — nem kívánták beépíteni a rendvédelmi szakképzést az állami iskolai rendszerbe. A különböző beosztásokhoz meghatározott állami iskolai végzettséggel kellett rendelkezni, ezt követően kerülhetett sor az adott beosztás betöltéséhez elöírt szaktanfolyam elvégzésére. Ennek alapjait a köztisztviselö minősítéséről szóló 1883 . évi törvény szabályozta, ${ }^{20}$ amely az állami alkalmazottak képesítési követelményeit határozta meg. Az eloírt feltételek biztosították a személyi állomány magas fokú képzettségét, felkészültségét. Továbbá rendkívül költségtakarékos megoldás volt a szaktanfolyami rendszer, hiszen a polgári oktatás intézményein alapult, így nem emésztett fel többletköltségeket rendvédelmi felsőfokú oktatási intézmények müködtetése. A rendszer lényege az volt, hogy az állami alkalmazottak a leendő hivatásuk eredményes ellátásához szükséges tudományterülettel az állami felsőoktatási képzés keretei között ismerkedtek meg. Ennek a tudományterületnek az állam müködése - esetünkben a rend védelme — terén keletkezett tapasztalatokkal az érintett tudományág alkalmazási lehetőségeivel és körülményeivel pedig a XXI. századi terminológia szerint, felsőfokú szakképzésben ismerkedhettek meg a jelöltek. A rendszer hasonlóan müködött az érettségihez és az elemi iskolai végzettséghez kötött beosztásokra jelentkezők esetében is. ${ }^{21}$

A detektívek képzési rendszere elsősorban a jelentkezők személyes képességeire és adottságaira épült. Képességeik felmérése alapján elsősorban a detektívfönök döntötte el, hogy a próbaszolgálatot követöen, melyik csoportba kerülnek beosztásra a gyakornokok.

Egy-két év gyakorlat után - melyet folyamatos monitorozás kísért - dőlt el, hogy véglegesen megmarad-e a gyakornok az eredeti csoportban, esetleg másik büncselekményekkel foglalkozó csoportba kerül, netán a legrosszabb esetben nem megfelelő teljesítmény nyújtása esetén elbocsátják. A tanfolyamok és szakvizsgák alapjai már 1890-ben megjelentek, intézményi szabályozására belügyminiszteri rendelettel, azonban csak 1923-ban a háború után került sor. ${ }^{22}$

Fegyverzet vonatkozásában a fővárosi rendőrség detektívtestületét csupán maroklőfegyverrel szerelték fel. Az őrszolgálati állományt azonban karabéllyal is ellátták. ${ }^{23}$

Mivel a detektív státuszok képesítési előfeltétele az állami iskolai végzettség tekintetében az érettségi volt, ezért a detektíveket besorolták az állami fizetési osztályokba. Ebből fakadóan pedig a detektívek számára biztosították a társadalmi állásukhoz méltó életvitelhez szükséges feltételeket. Fizetésük alkalmas volt egy család tisztes megélhetési költségeinek a fedezésére. Az általuk betöltött beosztás szintjétől és családjuk nagyságától függő alapterületủ és komfortfokozatú lakás lakbérének a teljes öszszegét megtérítette számukra az állam függetlenül attól, hogy az ország mely pontján teljesí-tettek szolgálatot. Emellett fizetésük $100 \%$-val voltak nyugdíjjogosultak 40 évi szolgálat után. Fizetésük néhány \%-os befizetése ellenében pedig ők és közvetlen családtagjaik teljes körű orvosi ellátásra tarthattak igényt. A detektívek számára tehát az állam — más alkalmazottaihoz hasonlóan — biztosította azokat a feltételeket, amelyek mentesítették a detektíveket a hétköznapi megélhetési gondok súlya alól. ${ }^{24}$

A fövárosi rendőrség detektív testületének nemcsak a szervezete és a létszáma növekedett dinamikusan, hanem a testület kötelékében szolgálatot teljesítő detektívek körében a szakmai tapasztalatok is gyarapodtak, továbbá a jogszabályi környezet is dinamikusan fejlődött. Létrejött a bünvádi perrendtartásról szóló 1896. évi törvény, amely — számos hasznos részlet szabályozása mellett — olyan alapfogalmakat is tisztázott, mint a rendőrhatóság fogalma stb. ${ }^{25}$

A bünvádi perrendtartásról szóló 1896. évi törvény rendelkezése értelmében „A nyomozás tárgya azoknak az adatoknak kipuhatolása és megállapitása, melyek a vád emelése vagy nem emelése kérdésében a tájékoztatására szükségesek. A nyomozás e határon túl nem terjedhet”26

E törvény nyomán pedig a belügyminiszter szabályozta a rendőrhatósági jogköröket, annak részeként a nyomozó tevékenységet is. ${ }^{27}$

A nyomozó rendőri hatóságok és közegek részére kiadott 1899. évi belügyminiszteri rendelet részletesen írta le a nyomozás feladatait. Ennek értelmében a nyomozás feladata a tényállás megállapítása és az adatok összegyüjtése, ami alapján a bíróság vizsgálata mellőzhető, illetve elegendő információ összegyüjtése a bíróság döntéséhez. RUDNAY Béla Budapesti Magyar Királyi Állami Rendőrség főkapitányának beszámolója szerint az 1881-es szabályozáshoz képest az 1896. évi büntető perrendtartási törvény bővítette a rendőrség hatáskörét, ebből kifolyólag több feladatot rótt a testületre. 
A beszámoló alapján a bünügyi osztály tekintetében 1899-ben 67 059, 1900-ban pedig 88556 ügyirat keletkezett. ${ }^{28}$

Tehát már ekkor is megfigyelhetö, hogy a változó törvényi háttér által a nyomozati jogkörrel rendelkező szervezeteknek egyre több feladattal kellett szembenézniük.

A detektívek munkáját nagymértékben megkönnyítette az 1885-ben létrehozott bünügyi nyilvántartás, ami számos egyéb újításhoz hasonlóan TÖRÖK János főkapitány nevéhez füződik. Ennek alapját a korábban rendörök által készített magánfeljegyzések alkották. ${ }^{29}$

A mai nyomozómunkában mindennapossá vált, álcázás, leplezés, rendőri mivolt elhallgatása, a korai detektívek körében is sokszor alkalmazott és bevált módszer volt. A detektívek gyakorta öltöztek előkelő uraknak, gázóra leolvasónak, koldusnak, sőt hölgyeknek is. ${ }^{30}$

A Budapesti Magyar Királyi Állami Rendőrség detektívtestülete a XIX-XX. század fordulóján már eredményesen fellépett a nemzetközi bünözői kapcsolatokkal rendelkező szervezett bünszövetkezetek ellen. Komoly szervezési tapasztalatokat, továbbá anyagi ráfordítást igénylö és üzemszerüen müködtetett büncselekményeket is felderítettek, illetve felszámoltak. ${ }^{31}$

Az életellenes cselekmények sikeres nyomozásának ékes példája az 1909-ben Adria Szállóban meggyilkolt prostituált esete. Az elkövetőt a fóvárosi detektívek néhány óra leforgása alatt, a mai szakmai zsargont alkalmazva forró nyomon üldözéssel kerítették kézre. Ebben az évben Budafokon ${ }^{32}$ löttek le egy kocsmárost ismeretlen elkövetők, akiket egy napi nyomozás után sikerült elfognia a testület tagjainak. Említésre méltó a megfigyelö-szolgálat kiépítése is, melynek során a detektívek figyelemmel tartották azokat a kétes hírü helyeket, játékbarlangokat, rendezvényeket, italmérő egységeket, ahol a rovott múltú vagy körözött, esetleg a közbiztonságot veszélyeztető elemek megfordulhattak. A megfelelő információk birtokában sor kerülhetett a zálogházi és egyéb inkriminált helyeken razziák megszervezésére, melyek alkalmával 1908-ban 500, 1909-ben 862 személyt fogtak el a detektív testület tagjai. ${ }^{33}$

A dualizmus időszakában dinamikusan fejlődő magyar főváros és a bünügyi munkát szabályozó jogszabályok változásai előidézték a detektív testület szabályzatának a fejlesztését is. A detektív osztály első szabályzata - napjaink terminológiája szerinti szervezeti és müködési szabályzata - belügyminiszteri jóváhagyással 1881. VII. 1-én lépett hatályba. ${ }^{34}$ Kilenc évvel később született az újabb detektív szabályzat, melyet 1890. VI. 1-én szintén a belügyi tárca vezetője gróf SZAPÁRY Gyula hagyott jóvá. ${ }^{35}$ Ezzel a fôvárosi rendőrségen belül a detektív testület élen járt, hiszen az örszemélyzet (közrendvédelmi állomány) számára külön szervezeti szabályzatát csak 1893-ban léptették életbe. ${ }^{36} \mathrm{~A}$ dualizmus idején jöttek létre a — fóvárosi rendőrséget szabályozó 1884 . évi belügyi utasítás nyomán ${ }^{37}$ — a fơvárosi rendőrség szakszolgálati ágait szabályozó szabályzatok, amelyeket a két világháború közötti időszakban alapvetően már csupán aktualizáltak. ${ }^{38}$

A fővárosi rendőrség szervezetére és szolgálatellátására vonatkozó jogszabályok a századfordulóra oly mértékben gyarapodtak, hogy a rendőrök időszerünek tartották a rájuk vonatkozó joganyag összegyüjtését és rendszerezését. Az első ilyen jogszabálygyüjteményt 1896-ban adták ki, majd 1902-ig évente kiegészítették és aktualizálták. Emellett a fővárosi rendőrség 1895-től az éves jelentéseit is publikálta, amelyek magukban foglalták a testületnek a tárgyévre vonatkozó legfontosabb adatait és eseményeit. ${ }^{39}$

A XIX-XX. század fordulóján izmosodó fővárosi rendőrség és annak részeként - a mennyiségi és minőségi mutatói tekintetében is gyarapodó - detektív testület nemzetközileg elismert tevékenységet valósított meg. ${ }^{40}$

Figyelemre méltó, hogy a dualizmus időszakában a főkapitányi tisztséget betöltő nyolc személy közül négy fő került ki csupán a fővárosi rendőrség személyi állományából, közülük azonban két főt dr. SÉLLEY Sándort és dr. SÁNDOR Lászlót — közvetlenül a detektív testület éléről neveztek ki rendőrfökapitánnyá 1892-ben, illetve 1917-ben. ${ }^{41}$

A fővárosi rendőrség detektív testülete oly vonzó példa volt, hogy a vidéki városok az önkormányzati rendörségeik kötelékében sorra állították fel a detektív testületeiket. ${ }^{42}$

A fővárosi detektív testület részt vett az államfő védelmében is. ${ }^{43}$

A fövárosi rendőrség detektív testületének az I. világháború alatti tevékenységét a személyi állomány szükössége is befolyásolta. A budapesti detektívek első rendszeresített létszáma csupán 36 fő volt, amely ugyan dinamikusan gyarapodott, azonban még békeidőszakban is elmaradt a létszámemelés az ügyek számának a növekedési ütemétől, illetve a feladatkörök gyarapodásától. ${ }^{44}$ 1914-ben a fővárosi rendőrség 2000 fö körüli létszámú őrszemélyzete mellett a detektív testületben 250 fö teljesített szolgálatot. Dr. DIETz Károly 1917-ben a fökapitányi kinevezésekor a fogalmazói karnak 29, a felügyelöi karnak 50, a detektív testületnek 400, az örszemélyzetnek pedig 4000 före való felemelését kérte. A háború alatt — hasonlóan a társ rendvédelmi testületekhez — számos rendőrt behívtak katonai szolgálatra, illetve sokan önként jelentkeztek katonának. Az ily módon elvont személyi állomány pótlása pedig nem valósult meg. A haderő kötelékében szolgálatot teljesítő rendőrök visszairányítása az 
anyatestületükhöz szóba sem jöhetett ugyan, amennyiben azonban valamilyen csoda következtében erre mégis sor kerülhetett volna a harctéren elesettekre már többé nem lehetett számítani. ${ }^{45}$

További megterhelést jelentett a kiszélesedő és szokatlan tartalmú feladatkör bővülés. Az új feladatkörök skálája rendkívül széles volt, ide tartozott az élelmiszerek uzsoraszerủ áremelkedésének a visszaszorításától, a középületek és közlekedési, valamint hírközlési csomópontok örzésén, a gyanús idegenek ellenőrzésén, a hadi ellátmánnyal üzérkedők kiszürésén, stb-n keresztül a kémek leleplezése is.

Ennek során nem csupán a helyi lakosok törvénysértő magatartását kellett felderíteni, illetve megelőzni vagy meggátolni, hanem a nem csekély számban például Gallíciából és Kárpátaljából érkező törvénysértő magatartást megvalósító személyeket is figyelemmel kellett kísérni, a tevékenységüket megakadályozni. A kiterjedt háborús hatáskör és azokban a szaporodó ügyek egyre nagyobb terhet jelentettek a szükös személyi állomány számára. ${ }^{46}$

A fővárosi rendőrség és annak részeként a detektív testület a számos nehézség ellenére is helytállt. Teendőit igyekezett minél eredményesebben megvalósítani, pedig közben még a területi illetékessége is gyarapodott. ${ }^{47}$

A fővárosi rendőrség detektívjei és őrszemélyzeti állománya az 1918-1919-es forradalmak tömegmegmozdulásának azonban már nem tudott gátat szabni. A szervezetet nem is ilyen céllal hozták létre, szervezeti felépítése, felszereltsége, a személyi állomány képzettsége, a rendelkezésre álló létszáma erre már tökéletesen alkalmatlan volt.

Különösen így volt ez 1919 tavaszán, amikor a 3000 főnyi rendőrség nem szállhatott szembe a kommunistákhoz pártolt 14000 főt számláló helyőrséggel és a nagyrészt felfegyverzett szociáldemokrata alakulatokkal. ${ }^{48}$

\section{A vidéki rendőrségek államosítása}

Kormányrendelettel nem lehetett egyensúlyt teremteni, elszigetelés jellemezte a rendőri tevékenységet, nem tudtak egymás ügymenetéről, eredményeiről. A polgármester és a közgyülés gyakran beleszólt a kapitányi hivatal munkájába. Korábban is számos kezdeményezés keletkezett a vidéki rendőrségek államosítására. 1886-ban a Polgármesterek Országos szövetsége is igényelte az államosítást, erről 1891 márciusában törvényjavaslat is született. 1912-ben a Magyar Királyi Belügyminisztérium is tervbe vették a vidéki és városi rendőrségek államosítását, azonban ez a nagy háború miatt meghiúsult. ${ }^{49}$

A háború alatt nem lehetett szó az átszervezésről, 1916-ban csupán a fiumei rendőrséget államosították. ${ }^{50} \mathrm{~A}$ háború utolsó évében WEKERLE Sándor a belügyi tárca vezetésével megbízott miniszterelnök 1918. VII. 9-én benyújtotta az erről szóló törvényjavaslatot, azonban az ősszel kitört forradalom miatt ekkor sem kerülhetett sor annak végrehajtására. ${ }^{51}$

A magyarországi tanácsköztársaság leverését követően az egyik legsürgetőbb feladat a rendőrség újjászervezése volt. Ennek végrehajtásáról az 1919. X. 1-én kiadott miniszterelnöki rendelet rendelkezett, ${ }^{52}$ amit az 1920. évi törvény ruházott fel törvényerővel. ${ }^{53}$ A rendelet végrehajtásával a belügyminisztert bízták meg, mint az állami rendőrség feletti legfelsőbb ellenőrző hatóság vezetőjét.

A rendeletben leírtak szerint a törvényhatósági jogú és rendezett tanácsú városokban a rendőrhatósági jogkört a magyar állami rendőrség gyakorolta. Indokolt esetben a belügyminiszter kiterjeszthette e hatáskört a községekre is. A határrendőrség és a budapesti állami rendőrség beolvadt az új magyar állami rendőrségbe, így Magyar Királyi Állami Rendőrség-ként egységes szervezetet alkotva. A törvényhatósági jogú és a rendezett tanácsú városokban rendőrkapitányságokat kellett szervezni. a kapitányságok működési területére tekintettel több város vagy község összevonható. Amennyiben a város külső területének nagysága indokolttá tette, kirendeltségek létrehozása lehetségessé vált.

A kirendeltségek az illetékes rendőrkapitányság felügyelete alatt látták el tevékenységüket. A rendőrkapitányságok felett pedig másodfokú rendőrhatóságként müködő és a kapitányságok felett ellenőrzést gyakorló kerületi rendőrkapitányságok álltak. A rendőrkapitányságok száma és müködési területe — a városokra kiterjedően - a rendőr kerületeknek, illetve a vegyesdandár-parancsnokságoknak a számával illetve területével voltak azonosak.

Az államosított rendőrség a szervezetében jogosult volt központi nyomozó hatóság müködtetésére. E hatóságnak az államrendészeti ügyek országos nyilvántartása, irányítása, ellenőrzése, az ügyek közvetlen intézése, tovább jelentős ügyekben a nyomozás irányítása és elvégzése volt a feladata. ${ }^{54}$

A témában született 1920. évi belügyminiszteri rendelet rendelkezett a tárca kebelében szervezett nyomozó osztály müködéséről. A fent felsorolt feladatokon kívül a rendelet a kémek elleni hathatósabb védekezés fokozását is feladatként említette. A nyomozó osztály a belügyi tárcán belül a rendőri főosztály alosztályaként került megszervezésre. Az osztály tagjai nyomozásuk tekintetében országos 
hatáskörrel bírtak. A rendelet alapján valamennyi rendőrhatóság, illetve a csendőrség minden jelentősebb eseményröl a nyomozó osztályt tájékoztatni, továbbá együttmüködni voltak kötelesek. ${ }^{55}$

1922. év végétől a Központi Nyomozó Hivatal hatásköre bővült, mivel az osztály végezte a vidéken történt bünesetek nyomozati munkáját is. Belügyminiszteri rendeletek nevesítettek azon bủneseteket, amelyek helyszínein közvetve, illetve közvetlenül eljárhattak. ${ }^{\mathbf{5 6}}$

Az ország valamennyi városára kiterjedő hatállyal működő kerületi rendőr-fökapitányságokat a csendőr kerület-parancsnokságok számarányában és székhelyei szerint szervezték meg, ezzel valóban kedvezőbb feltételeket teremtettek a rendőrség és a csendőrség összehangolt tevékenységének elősegítése céljából. A városi rendőrkapitányi hivatalok a vidéki rendőrségek államosítását megelőzően a városok alsó fokú közigazgatási, iparhatósági szervei is voltak. Az államosítást követően bizonyos rendészeti ügyek visszamaradtak a városi hatóságok hatáskörében. A törvényhatósági jogú városok emiatt megszervezték az elsőfokú közigazgatási hatóságokat /városi elöljáróságokat/, melyek fö feladata: a közegészségügyi, állategészségügyi, közsegélyezési ügyek intézése, gyárak felügyelete, hatósági bizonyítványok kiadása, hagyatéki leltározás, tüzrendészeti, iparrendészeti feladatok voltak. Élén a városi tanácsnok állt, önálló iktatója, iratkezelése volt. A kihágási ügyek intézése érdekében külön rendőri büntetőbíró került kijelölésre. Az államosítást követően tehát a városi kapitányi hivatalok utódszerve a törvényhatósági jogú városok közigazgatási apparátusán belül az első fokú közigazgatási hatóság lett. Ez a rendszer egészen 1950 második félévéig szerepelt a törvényhatósági jogú városok történetében. ${ }^{57}$

\section{Budapest}

A proletárdiktatúra bukását követően 1919. VIII. 9-én dr. MATTYASOVSZKY Györgyöt kérték fel a budapesti fökapitányi tisztség betöltésére, aki ekkor a belügyi tárca tanácsosa volt. A fökapitány a legnehezebb időkben kapta feladatul a budapesti rendőrség újjászervezését. A kommunista rendszer a hagyományos értelemben vett rendöri intézményt megszüntette, helyette a Vörös Örség néven debütáló politikai irányítás alatt álló elnyomó szervezetet hozott létre. A fő́kapitány erős kézzel megkezdte a tiszti kar, valamint a legénységi állomány igazolási eljárásait. A helyzetet csak nehezítették a román hadsereg által elkövetett sorozatos fegyveres büncselekmények, valamint a rohamosan növekvő élet és vagyon elleni deliktumok. A Budapesten székelő antant-bizottság a rendőrség újjászervezésének felügyeletét, vagyis a fökapitány minden intézkedését román illetékesség alá helyezte. Az úgynevezett hagyományos bünesetek mellett a személyi állománynak meg kellett küzdenie az egyre nagyobb teret nyerő antiszemita mozgalmak jogellenes tevékenységével. A románok kivonulásával 1919. XI. 14-én, majd HORTHY Miklós 1919. XI. 16-ai bevonulásával új korszak vette kezdetét a rendőrség történetében. ${ }^{\mathbf{5 8}}$

A főkapitányt egy év után dr. NÁDOSY Imre váltotta, aki hivatalát 1920. VIII. 4-én foglalta el. Elődje után folytatta az újjászervezést, felismerve a szervezet hiányosságait igyekezett azokat kijavítani. Áthelyezésekkel, az illetmény emelésével, segélyekkel, jutalmakkal igyekezett javítani a morált, munkakedvet. Ismét bevezette az intéző és végrehajtó tisztikar vizsgáit. Az oktatás minőségét személyesen is ellenőrizte, közterületi szolgálatot rendelkezése alapján csak rendőrképesítő tanfolyam végzett rendőr láthatott el. NÁDOSY Imre 1921. VIII. 16-án távozott tisztségéből, ekkor az első országos fökapitánnyá került kinevezésre. Ezt követően országos szinten folytatta azt a munkát, amivel a fővárosi rendőrség színvonalát nagymértékben emelte. Az említett két fökapitány időszakában kerültek kimunkálásra azok az alapok, ami a szilárd államrendőrség müködéséhez elengedhetetlenek. A hagyományos közrend és közbiztonság szavatolását célzó rendőri erők mellett, ekkor épültek ki az állambiztonsági szervezetek és intézmények. Az 1920. évi törvényi szabályozás alapján ${ }^{59}$ a rendőrség újjászervezése keretében felülvizsgálták az állomány proletárdiktatúra alatt tanúsított magatartását, ennek során megbízhatatlanságra hivatkozva 50 fö került elbocsátásra. ${ }^{60}$

\section{A fövárosi detektívek 1919-töl}

Az igazolási eljárások a detektívtestület tagjait is érintették, így indulhatott meg a rendőrség megtisztítása a forradalmi, kommunista elemektől, akiket ezt követően igyekeztek nagy erőkkel felkutatni. E tevékenységet az 1919 augusztus hónapban szervezett politikai osztály végezte, amely a fökapitányság bünügyi osztálya mellett müködött. ${ }^{61}$ Munkájuk javarészt akkor kezdődhetett meg, amikor a román megszálló csapatok elhagyják Budapestet, és 1919. XI. 16-án HORTHY Miklós csapatai élén bevonult a fövárosba. A forradalmi, kommunista elemek felkutatásán túl nagy feladatot rótt a detektívtestületre a zavaros időkben elharapódzó bủncselekmények visszaszorításának terhe. Ennek eredményes végrehajtása érdekében a kormány a kiemelt büncselekmények elkövetöivel szemben statáriumot hirdetett. A betörések, lopások száma még így is ijesztő méreteket öltött. Megindult a nyomozás gróf TiszA István meggyilkolásának ügyében, amely négy hónapon át tartott, a detektívek több mint 600 személyt hallgattak ki, 16 letartóztatás történt. 1919. VIII. 14-től a detektívek tevékenységét nehezítette a román 
megszállás következtében kialakult intézkedési szabadság korlátozása, valamint a létszámhiány. Ennek ellenére 1919 augusztusától az év végéig 52821 bünügyi nyomozást végeztek a detektívek, ebből 42 554 került eredményes lezárásra. Több eredményes razziát is szervezett a testület a fővárosban. A kommunista büncselekmények nyomozását végző politikai osztály mellé különálló detektívcsoportot osztottak be. A politikai osztály 1920 őszén szünt meg, feladatait egy rendőrtisztviselő vezetése alatt álló 52 főből álló politikai főcsoport látta el. Az internálási ügyekkel külön 18 főből álló csoport foglalkozott, az idegenforgalom ellenőrzése érdekében pedig útlevélosztály került felállításra 27 detektívből. A bünügyi nyomozás eredményesebb és gyorsabb szavatolása érdekében úgynevezett „repülő" csoportot állítottak fel egy föcsoportvezető irányítása alatt. A föcsoport hat alcsoportból állt, amelybe összesen 58 detektív teljesített szolgálatot. Feladatuk a bünvádi feljelentést követően az azonnali intézkedések megtétele volt. Az 1920. év kezdetén 543 detektív látta el feladatát, közülük 135 került elbocsátásra, helyükbe 47 új detektív került kinevezésre. Ügyforgalom tekintetében 1917-hez képest az 1920-as év 70\% -os emelkedést jelentett. A trianoni békediktátum nyomán a föváros megtelt az elcsatolt területekröl menekülőkkel, ami fokozott figyelmet követelt a testület tagjaitól. ${ }^{62} \mathrm{Az}$ illetmény, életkörülmények területén javulás mutatkozott, az állami tisztviselők státusza megerősödött.

A feladatok továbbra sem ritkultak: árdrágítási ügyek felderítése, valutaüzérek, csempészek elfogása, prostitúció megfékezése is a palettán szerepeltek. ${ }^{63}$

A detektívek a titkos kommunista gyüléseken is részt vettek, egyéb államra veszélyesnek ítélt csoportokat figyeltek. 1920-ban és 1921-ben számos a rendőrséget érintő rendelet került kiadásra, melyek a már országos hatáskörü testület hatáskörét, szervezetét rendezték. A személyi állomány házassági ügyeiről, tisztelgési, fegyelmi szabályairól is rendelkeztek. A detektívek létszámát NÁDOSY Imre fökapitánysága alatt 550 före emelték fel.

A személyi állomány jelentős része müvelt, nyelveket beszélö, egyetemet végzett férfi volt. Az ideiglenes minősítésű detektívek az 1921-től szakoktatásra voltak kötelezettek, véglegesítésük csak az eredményes vizsga letételét követően vált lehetővé. A detektív szakoktatás részleteit a főkapitány helyettes dolgozta ki, amelyet 1923-ban rendeletben is rögzítettek. ${ }^{64}$

A detektív testület tagjai számára kétféle tanfolyamot és vizsgát a detektív és a detektívfelügyelöit rendszeresítették. Az alap detektívtanfolyam keretén belül a résztvevők többek között közigazgatási ismereteket, kriminalisztikát, büntetőjogot hallgattak, megismerkedtek a szolgálati szabályzattal, lövészetet, birkózást és egyéb gyakorlati ismeretket is szereztek. Boncoláson vettek részt, hogy megismerjék az emberi test anatómiáját, mellyel szintén a gyakorlatban használható fontos tudás birtokába kerültek. A detektívfelügyelői tanfolyam részletesebb és mélyebbre menő ismeretanyaggal szolgált, melyben az önálló munkavégzésre és vezetésre alkalmas kiválasztottak részesültek, ez a későbbi előrehaladás egyik lépcsőfoka volt. A tanfolyamok szóbeli és írásbeli vizsgával zárultak. ${ }^{65}$

1921-ben a testület létszámát 180 fővel szaporították, így 653 fővel rendelkezett a személyi állomány. Felállították a repülő csoportokat, valamint a 12 főcsoport mellé 43 alcsoportot osztottak be. Ezzel az eddigieknél is jobban specializálódtak a büncselekményi kategóriáknak megfelelően. Az adott területen legtöbb tapasztalattal rendelkező detektívek kerültek a megfelelő csoportokba.

Az 1921-es statisztika 127424 bünügyben 67458 eredményes nyomozást takart, ami a bagatell büncselekményekre, valótlan bejelentésekre tekintettel kiváló eredménynek számít. 2072 razzia került megszervezésre, melynek során 6170 fö elöállítás, 910 fö körözött személy elfogása, 622 fő a főváros területéről kitiltott, valamint 622 fő munkakerülő egyén lett intézkedés alá vonva. Az évben a nyomozásokkal és razziákkal együtt összesen 41008 fő került előállításra. Az elkövetkező néhány évben az intellektuális bünelkövetés elszaporodása volt a jellemző, tőzsdejáték, valutázás, sikkasztás, okirat hamisítás, csempészet képezte a bünügyi statisztika jelentős részét. Ennek oka főként gazdasági volt, hiszen a pénz romlott, a valuta ingadozott, a tőzsde gyakorlatilag összeomlott. A nyomozást nehezítette a csonka Magyarország határain keresztül menekülők nyomon üldözése. A szomszédos államok nem mutatkoztak segítőkésznek, sőt olykor gátolták az eredményes felderítést.

1922 júliusában az állomány létszáma 671 fő volt. ${ }^{66}$ Ekkor a föcsoportok az alábbiak szerint tagozódtak: a sérülési, vasúti, lopási, intellektuális, repülő, kerületi kapitánysági, pályaudvari kirendeltség, politikai. Támogatásukra 45 alcsoport volt hivatott, ami a későbbiekben 69-re bővült. A detektívfőnök a bünügyi osztály vezetését magánál tartotta és megkísérelte azt egyesíteni a detektívtestület vezetésével. A közel egy évig tartó kísérlet azonban nem zárult sikerrel, mivel az ügyek oly mértékben elszaporodtak, hogy annak az eredményes felderítés látta kárát. 1924-ben a detektívek létszáma 719-re emelkedett, ennek részbeni magyarázata, hogy 1924-ben az Országos Központi Nyomozó Hivatal feloszlott, innen 169 detektívet helyeztek át a testületbe. Az áthelyezettek, korábbi tevékenységükre tekintettel a 
politikai főcsoporthoz kerültek besorolásra. Az évben két új a valutaellenőrző és utazási ellenőrző alcsoport került felállításra.

A politikai fócsoportot kivették a testületből és a bünügyi osztály alá sorolták. A statisztikai adatok vizsgálata során megállapítható, hogy 1922-ben 178 237, 1923-ban 190162 addig 1924-ben 132292 ügy keletkezett a testület kezelésében. A kitiltottak, közveszélyes munkakerülők, razzia során elfogott, előállított körözött személyek száma is erősen csökkent az előző évekhez képest. A háború és forradalom által sújtott fővárosba lassan, visszatért a békeidőket idéző kriminológiai környezet.

Az 1901-ben alakult Nyugdíjpótló és Segélyező Egyesület az 1920-as években is tevékenyen látta el feladatát. ${ }^{67}$ Az egyesület tevékenységéhez köthető a detektívek baleseti és haláleseti biztosítása, a taglétszám bővítése. A szervezet a Magyar Királyi Állami Rendörség vidéki főkapitányságain belül is megerősödött. Ruhanemü részletfizetésére adtak lehetőséget, valamint az 1922. évi alapszabály módosítás értelmében az előző állami szolgálatban eltöltött éveket is beszámították a tagsági évekbe, annak érdekében, hogy a nyugdíjpótlékot 2000 koronára emelhessék. 1923-ban a tagdíjakat 100 szorosára emelték, ezzel együtt a temetkezési hozzájárulást, segélyeket, nyugdíjpótlékokat a 20 szorosára emelték. A tagok családtagjai részére ingyenes orvosi rendelő került felállításra. Az egyesület tagjainak létszáma 1923-ban 1 144-volt. ${ }^{68}$

\section{Bünesetek a fơvárosban}

Egyenruhát viselő egyének és a rendőrség között is robbantak ki csatározások. A fóvárosi rendőrség a haderő Budapesten állomásozó csapataival együttmüködve fegyverezte le a „britanniás különítményt”, amelynek a tagjai az utcán garázdálkodtak és fosztogattak. Ennek nyomán belügyminiszteri rendelet született a katonai egyenruha jogtalan viselésének tárgyában.

Az 1920-as évek inflációját több bünöző is kihasználta. Egy szélhámos páros ismerőseitől 500000 dollárnak megfelelő magyar koronát csalt ki valutavásárlásra hivatkozva.

1923-ban a 27 éves orvostanhallgató, korábbi banktisztviselő az államtól sikkasztott a rendőrség „segítségével”140 milliót, oly módon, hogy felajánlotta segítségét a rendőrségnek valutaüzérek leleplezésére. Kérésének megfelelően a fenti összegnek megfelelő valutát a Hitelbankba vittek, ahol az elmondása alapján általa ismert tisztviselő, mint összekötő fogja kapcsolatba hozni a valutázókkal. Az öt kísérö két detektív a Hitelbank elöterében várakozott a szélhámos soha be nem következő jelzésére, mivel ő az intézmény egy másik kijáratán távozott a valutával együtt.

1922-ben az újságok címlapján „Hullákat csempésztek külföldre a bonctani intézetböl” megjelent cím is komoly országon átívelő bünesetet takart. Hozzátartozók nélküli, elhunyt személyek hulláit csempészték külföldre. Az Anatómiai Intézetben feltünt, hogy egyre kevesebb holtest érkezik, ezáltal akadozik korbonctani oktatás. A történet mögött a Rókus Kórház halottasház altisztjének és az Anatómiai Intézet föpreparátorának bünös tevékenysége állt. A beszállított holttesteket preparálták, majd ládákba csomagolták és eladták Berlin, Bécs, London és Párizs anatómiai intézeteinek, illetve magáncélokra. További nehézséget rótt a testületre a hazatért hadifoglyok beilleszkedése. ${ }^{69}$

\section{Polgárörség megszervezése}

A közbiztonság megszilárdítása kiemelten fontos feladat volt, mint ahogyan az ma is. A közbátorság, köznyugalom, közbiztonság erősítése érdekében szükség volt önkéntes rendfenntartó csoportok közremüködésére. Azonban a belügyi tárca illetékesei ezen önkéntesek alatt nem a különítményekre gondoltak, hiszen azok gyakran szélsőséges politikai elveket vallottak, a közvélemény ellenszenvét vívták ki tevékenységükkel. Ezért a kormány a megoldást a csendőrség és a rendőrség munkáját segíteni tudó polgárörség felállításában látta. 1921-ben a katonai és rendőri szervek kezdték meg a polgárőr csoportok szervezését. Jelentősége a falvakban volt erőteljesebb, itt az 5-8 fős csendőr őrsöket 20-30 fös polgárör szakasszal erősítették meg. A polgárőrség megszervezésre a vármegyékben is folyamatos volt, a háború és a forradalmak idején elszaporodott fegyveres garázda csoportok megfékezése érdekében például a Szeged környéki tanyákon 1000 fö felfegyverzése történt meg. A polgárörök nagy része katonaviselt volt, a parancsnokok tartalékos tisztek voltak. 1921 áprilisában mintegy 50000 polgárőr segítette a csendőrség és a rendőrség munkáját több parancsnokság alárendeltségében. ${ }^{70}$

Összességében megállapítható, hogy a magyar rendőrségek államosítása egészen a magyarországi tanácsköztársaság bukásáig váratott magára. Igény az államosításra már az 1848-1849-es magyar forradalom és szabadságharcot megelőzően is felmerült, azonban a HABSBURG-birodalom központi hatalmának magyarellenes beállítottsága, majd az 1848/1849-es magyar forradalom és szabadságharc honvédő harcai miatt ez meghiúsult, majd az I. világháború akadályozta meg az erre irányuló törekvéseket. Végül az államosítás folyamata elkerülhetetlenné vált, felismerve a történelmünk során keletkezett igényeket és kudarcokat. Továbbá nem elhanyagolható hatást gyakorolt az államositás szükségességére a fővárosi rendőrség 1881-ét 
követő sikerei és rohamos fejlődése, ami hangsúlyozta a vidéki bünüldöző szervek elmaradottságát. Ezzel kezdetét vette a fejlődés szilárd alapjául szolgáló országos szervezet kiépülése. Véleményem szerint ezek az egységes és általános garanciák elengedhetetlenek a minőségi bünüldöző apparátus kiépítéséhez, akár a képzésnek, akár a személyi állomány javadalmazása, egységes törvényi háttérének a tekintetében.

A detektívtestület történetében az 1919-es forradalmak elötti, majd az ezt követő időszak a maga nehézségeivel egyetemben felfelé ívelést jelentett, gondoljunk a dualizmusban megszilárduló nyomozási metodikákra, majd a törvényi szabályozás fejlődésére, konkretizálására. A magyarországi tanácsköztársaság bukását követő időszakban a szaktanfolyami rendszer bevezetésére, segélyező egyletre, sportegyesületre. Minden egyes ilyen elem a testület nívós mivoltát erősítette, alapvető szolgálatuk azonban a dualizmushoz képest nem változott.

Történelmünkből okulva, ahogy azt rendvédelmi testületeink története igazolja az önkormányzati modell hazánkban, annak sajátosságaira tekintettel nem életképes. Az egyes feladatkörök kiszervezése, áttétele segítheti a testület munkáját, csökkentheti bürokratikus terheit. Például a nem kifejezetten a nyomozó munka szerves részének tekinthetö feladatkörök átadása a közigazgatásnak jó irányba mutató szervezési lépések voltak, sajnálatos módon ennek napjainkban az ellenkezője érvényesül. Számos korábban nem a rendőrség által végzett ilyen tevékenység került vissza a testület ügykezelésébe.

A detektívek fokozott közterületi jelenléte is példával szolgálhat korunk bünüldözöinek, hiszen megfelelő személy- és helyismeret nélkül a nyomon üldözés nehézkessé válhat. Társadalmunk változása, a technikai fejlődés dacára úgy vélem, hogy az eredményes detektívmunka elengedhetetlen feltétele a feladatellátás közegének megismerése. Ennek erős bástyája lehet a társadalomtudományi tárgyak fokozott oktatása a rendőri szakokon, oktatási intézményekben. Azonban a bürokratikus terhek növelésével a közterületen töltött idő mértékének meghatározása általában nem saját belátás szerint történik. 
Jegyzetek:

${ }^{1}$ ZACHAR: 20-24.p.

${ }^{2}$ CSIZMADIA: A magyar közigazgatás fejlödése a XVIII. századtól a tanácsrendszer létrejöttéig. 79-80.p.

${ }^{3}$ PARÁDI: A magyar rendvédelem 1867-1918. 33-42.p.

4 1870/XLII.tc. ; 1871/XVIII.tc.

5 A polgári magyar állam katonailag szervezett fegyveres őrtestülete volt:

- a Magyar Királyi Csendőrség 1881-1945 (Központi Nyomozó Parancsnokság 1930-tól);

- a Magyar Királyi Nemesi Testőrség 1867-1919 (nyomozó részleggel nem rendelkezett);

- a Magyar Királyi Darabont Testőrség 1904-1919 (nyomozó részleggel nem rendelkezett);

- a Magyar Királyi Testőrség 1920-1945 (nyomozó részleggel nem rendelkezett);

- a Magyar Királyi Koronaőrség 1867-1945 (nyomozó részleggel nem rendelkezett);

- a Magyar Királyi Folyamőrség 1920-1939 (nyomozó részleggel rendelkezett);

- Magyar Királyi Vámő́rség 1921-1931 (nyomozó részleggel rendelkezett);

- Magyar Királyi Határőrség 1932-1938 (nyomozó részleggel rendelkezett)

- Magyar Királyi Képviselőházi Örség 1912-1945 (nyomozó részleggel nem rendelkezett).

A polgári magyar állam polgári fegyveres örtestületei voltak:

- Budapesti Magyar Királyi Állami Rendőrség 1872-1919 (detektív testület 1885-töl);

- Magyar Királyi határrendőrség 1906-1918 (detektív csoporttal rendelkezett);

- Fiumei Magyar Királyi Állami Rendőrség 1916-1918 (detektív csoporttal rendelkezett);

- Magyar Királyi Állami Rendőrség 1919-1930 (detektív testület);

- Magyar Királyi Rendőrség 1931-1945 (detektív testület)

- Magyar Királyi Pénzügyőrség 1867-1945 (nyomozó „szakszolgálati ág” müködött 1930-tól)

- Magyar Királyi Vám- és Adóőrség 1872-1886 (nyomozó részleggel nem rendelkezett).

PARÁDI: Rendvédelmi testületek a polgári magyar állam időszakában 1867-1919. ; Idem: A katonailag szervezett őrtestület és a polgári örtestület.

6 Idem: A Magyar Királyság rendvédelme 1867-1919. ; Idem: A magyarországi rendvédelem fejlődési tendenciái $1867-$ 1950. ; Idem: A dualizmuskori magyar rendvédelem. ; Idem: A két világháború közötti Magyar Királyság rendvédelme. Idem: A polgári magyar állam rendőrségei 1867-1945.

7 1872/XXXVI.tc. ; 1881/XXI.tc.

8 „Sárga könyv”-nek nevezték a kortársak azt a sárga színủ borítóba kötött könyvet, amelyben a szerzők összegyüjtötték a bủnügyi eljárások kívánatos korabeli szabályait. E téma átfogó törvényi szabályozásának a létrejöttéig a szakma a „Sárga könyv"-ben foglaltakat tekintette mérvadónak.

${ }^{9}$ 1881.XXI.tc. op.cit. I.Fejezet. 1-3. §

1043 972/1884. BM.r.

${ }^{11}$ KopASZ:131-159.p.

${ }^{12}$ Ilyen rendbiztosok voltak: ZLINSZKY Károly, URS Nándor, MÁLTÁs Hugó.

${ }^{13}$ BORBÉLY - KAPY: 17.p.

14 1878/V.tc. ; 1879/XL.tc.

${ }^{15}$ BORBÉLY - KAPY: op.cit. 15-17.p.

${ }^{16}$ Loc.cit. 21-22.p.

${ }^{17}$ A fővárosi detektívtestület főnökei voltak a dualizmus időszakában: SPLÉNYI Ödön (1886-1889), SzOMBATFALVY Albert (bünügyi nyilvántartás, sajtóiroda. 1889-1899), RUTTNER Sándor (1899-1901), KRECSÁNYI Kálmán (daktiloszkópia 19011912), NAGY Károly (1912-1917), dr. JESZENSZKY Gellért (1917-1918).

Loc.cit. 239-240.p.

18 VÉCSEY: 24.p.

${ }^{19}$ Loc.cit. 248.p.

${ }^{20} 1883$ /I.tc.

${ }^{21}$ PARÁDI: Rendőr tisztképzésünk hagyományai 1867-1945.

${ }^{22}$ VÉCSEY: op.cit. 247-249.p.

${ }^{23}$ PARÁDI: Rendvédelem - karhatalom 1867-1945. 112-117.p.

${ }^{24}$ PARÁDI: A magyar rendvédelem személyi állományának szociális viszonyai 1867-1945. 57-60.p.

25 1896/XXXIII.tc. ; 3 200/1899. (VIII. 15.) IM.r.

${ }^{26} 1896 /$ XXXIII.tc. op.cit. 83. §

27130 000/1899. (XII. 22.) BM.kr.

${ }^{28}$ RÉDEY: 9-18.p.

${ }^{29}$ A módszerrel antropológiai jellemzőket alkalmazva azonosították a személyeket, például a csontozat sajátosságai, fül, fej és végtagok mérete, egyéb jellemző ismertetőjegyek alapján.

${ }^{30}$ PÜSPÖKY-KELLER Mihály detektívfelügyelő napokig figyelt egy bérházat társával magukat rongyos ruházattal álcázva. A lakóházba ki és bejártak, találkoztak a lakókkal, de az emberek nem sejtették valódi kilétüket. Ezzel elegendő információt szereztek, hogy beazonosítsák és elfogják a hatóság által keresett csoportot. LEVICZKY Sándor detektív álruhában derített fel egy vendéglátó egység működése mögé rejtett játékbarlangot. KLACSÓ Kálmán detektív postásnak álcázva magát nyert bebocsátást a keresett vagy bújtatott személyek lakásába. Dr. KотоFF Olivér detektívfelügyelő egy őrökkel és figyelőszemélyzettel ellátott játékbarlangot derített fel, oly módon, hogy elegáns úrnak öltözve magát bárónak kiadva, két hölgynek álcázott detektívtársával jutott be a belvárosi magánlakásba.

BORBÉLY - KAPY: op.cit. 254-258.p.

${ }^{31}$ A budapesti detektívek eredményes felderítéséből említésre méltó a több országban körözött betörők PAPAKOSTA és társainak elfogása, az 1884-ben történt postarablás elkövetőjének, CsOMBOR Imrének a felkutatása és kézre kerítése.

Loc.cit. 249-250.p.

${ }^{32}$ Ekkor még nem volt a főváros része, hanem az agglomerációhoz tartozott, mivel azonban a fővárosi rendőrség számára lehetőség nyílt arra, hogy jogszabályi felhatalmazás alapján az agglomerációban is tevékenykedjen, ezért meg tudták akadályozni a fóváros körül bünözői gyürü létrejöttét.

1889/XLVI.tc. ; 1912/LX.tc.

${ }^{33}$ VÉCSEY: op.cit. 43-45.p.

${ }^{34} \mathrm{~A}$ belügyi tárca élén TISZA Kálmán állt, aki egyben miniszterelnök is volt. BÖLÖNY: 294.p.

${ }^{35} 1890$-ben a belügyi tárcát gróf SzAPÁRY Gyula vezette.

Loc.cit. 284-285.p. 


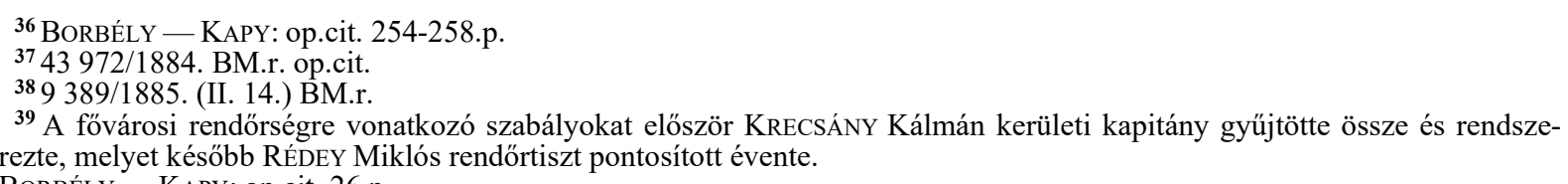

A testületre vonatkozó — immár az államosított magyar rendőrség egészére kiterjedően — újabb szabálygyüjtemény létrehozására 1926-ban került sor.

NÉMETHY - TÖRÖK

${ }^{40}$ BORBÉLY - KAPY: op.cit. 25.p.

41 Nem a fóvárosi rendörség kötelékéből került kinevezésre THAISZ Elek (1873-1884), JEKKELFALusY Lajos (1884-1885), TÖRÖK János (1885-1892), RUDNAY Béla (1896-1906). Dr. BODA Dezső határeset, mivel a fővárosi rendőrség kötelékéből debreceni kormánybiztossá kinevezett BODA Dezsőt feladata kiváló teljesítése nyomán nevezték ki a fővárosi rendőrség élére. A fővárosi rendőrség személyi állományából nevezték ki a főváros rendőr-főkapitányává dr. SÉLLEY Sándort (1892-1895), dr. SÁNDOR Lászlót (1917-1918) és dr. DIETz Károlyt (1918-1919).

BORBÉLY - KAPY: op.cit. 75-91.p.

42 TISZA

${ }^{43}$ PARÁDI: Az államfő testőrségei az Osztrák-Magyar Monarchiában.

${ }^{44}$ Például a kivándorlási törvény intézkedéseinek ellenőrzése a pályaudvari kirendeltség feladatává is vált, amely az őrszemélyzet és a detektív testület tagjaira egyaránt a korábbinál lényegesen több teendőt rótt.

BORBÉLY - KAPY: op.cit. 31.p.

${ }_{45}$ A fővárosi rendőrség tagjai közül az I. világháború során a harctéren hősi halált halt, vagy sebesülésbe és betegségébe belehalt, továbbá eltünt összesen 57 fö.

Loc.cit. 39-40.p.

46 A budapesti detektívek 1915-ben 37077 megbízást kaptak, amelyből 33270 nyomozás volt sikeres. 1916-ban azonban már 81723 aktát intéztek el.

Loc.cit. 37-38.p.

47 1916-ban a fövárosi rendőrség hatáskörét kiterjesztették — az akkor még Budapest agglomerációjába tartozó — Csepel községre is. Ez nem az első eset volt, mivel a fövárosi rendőrség létrehozása óta több agglomerációs település is a hatáskörébe vontak.

1916/XXXVIII.tc.

${ }^{48}$ BORBÉLY - KAPY: op.cit. 48.p.

${ }^{49}$ KoPASZ: op.cit. 131-159.p.

50 1916/XXXVII.tc.

51 VÉCSEY: op.cit. 60-63.p.

525 047/1919 számú ME.r.

53 1920/I.tc.

${ }^{54}$ KopASZ: op.cit.

5531 300/1920. (V. 19.) BM.r.

${ }^{56}$ VÉCSEY: op.cit. 64.p.

${ }^{57}$ KOPASZ: op.cit.

58 BORBÉLY - KAPY: op.cit. 92.p.

59 1920/XI.tc.

${ }^{60}$ KESERÜ

${ }^{61}$ Az osztályt BoTÁR Béla rendőrfőtanácsos, továbbá a fökapitányság Margit körúti egységét CzöVEK Sándor rendőrfőtanácsos vezette.

62 1920 augusztusában a detektívtestület irányítását NAGY Károly detektív főnök főkapitány helyettes áthelyezését követően CZIBOR Ferenc rendőrtanácsos vette át.

${ }^{63}$ VÉCSEY: op.cit. 60-63.p.

${ }^{64}$ Loc.cit. 65.p.

${ }^{65}$ Loc.cit. 247-249.p. ; 9 270/1922. (X. 10.) ME.r. ; 18 881/1923. (X. 5.) BM.r.

${ }^{66} 1922$ júliusában a detektívek élére a detektívfőnöki állást betöltve dr. ANDRÉKA Károly budapesti rendőrfőkapitány-helyettes került kinevezésre.

${ }^{67}$ A segélyezö egylet ekkor DEÁK János detektívfelügyelő elnöksége alatt állt.

${ }^{68}$ VÉCSEY: op.cit. 65-74.p.

${ }^{69}$ KESERÜ: op.cit.

${ }^{70}$ Loc.cit. 
Forrás- és irodalomjegyzék (a jegyzetekben alkalmazott röviditések oldása):

\section{MONOGRÁFIÁK KISMONOGRÁFIÁK ÉS HASONLÓ JELLEGÜ KÖTETEK}

BORBÉLY - KAPY

$(13 . ; 15 . ; 16 . ; 17 . ; 30 . ; 31 . ; 36 . ; 39 . ;$ 40.;41.;44.;45.;46.;48.;58.;)

CSIZMADIA

(2.;)

KESERÜ

(60.;69.;70.;)

RÉDEY

(28.;)

TisZA

(41.;)

\section{TANULMÁNYOK}

KOPASZ

(11.;49.;54.;57.;)

PARÁDI József: Rendőr tisztképzésünk hagyományai 1867-1945. (21.;)

PARÁDI: A Magyar Királyság rendvédelme 1867-1919. (6.;)

PARÁDI: A magyarországi rendvédelem fejlődési tendenciái 18671950 .

(6.;)

PARÁDI: A magyar rendvédelem személyi állományának szociális viszonyai 1867-1945.

(24.;)

PARÁDI: A dualizmuskori magyar rendvédelem.

(6.;)

PARÁDI József: A két világháború közötti Magyar Királyság rendvédelme.

(6.;)
BORBÉLY Zoltán — KAPY Rezső: (szerk.): A 60 éves magyar rendőrség 18811941. Budapest, 1942, Halász Irodalmi és Könyvkiadó Vállalat. I.köt. 1-299 p. II.köt. 300-600 p.

- Csizmadia Andor: A magyar közigazgatás fejlödése a XVIII. századtól a tanácsrendszer létrejöttéig. Budapest, 1976, Akadémia Kiadó. 560 p. HU-ISBN 963 0507137.

— KESERÜ István: Fejezetek a M. kir. Belügyminisztérium történetéböl 1919-1926. Budapest, 1994, Belügyminisztérium. 58 p. HU-ISBN 963770390 X. /Fejezetek a Magyar Királyi Belügyminisztérium történetéböl./ HU-ISSN -

- RÉDEY Miklós: A nyomozási eljárás nehézségei. Budapest, 1901, Légrády Testvérek. $68 \mathrm{p}$.

- Tisza Miksa: Magyarország rendörségének története a legrégibb időktöl 1912-ig. Igló, 1913, Szepesi Lapok Nyomda. 327 p.

- Kopasz Gábor: A magyar városok rendészete a dualizmus korában. Levéltári Szemle, XIII.évf. (1963) 1-2.sz. 131-159.p.

PARÁDI József: Rendör tisztképzésünk hagyományai 1867-1945. 35-51.p. In DÁNOS Valér (szerk.): A rendőrképzés reformja a kelet-európai változások tükrében. Budapest, 1991, BM Rendészeti Kutató Intézet. HU-ISBN — /Tanulmányok a rendészet köréböl./ HU-ISSN - A tanulmány korábbi változata 1991. november 12-én Balatonföldváron hangzott el a Rendörtiszti Föiskola által szervezett rendvédelmi szakképzési konferencián. A publikált tanulmány az előadás javított, bővített és átdolgozott változata.

PARÁDI József: A Magyar Királyság rendvédelme 1867-1919. Rendvédelem-történeti Füzetek (Acta Historiae Praesidii Ordinis), IX.évf. (1999) 10.sz. 98-147.p. HU-ISSN 1216-6774. A tanulmány korábbi változata 1998. szeptember 22-én, Budapesten hangzott el a Szemere Bertalan Magyar Rendvédelem-történeti Tudományos Társaság által szervezett rendvédelem-történeti tudományos konferenciasorozatnak ,A nyugati rendvédelem hatása a XIX-XX. századi magyar rendvédelemre" címü $X$. konferenciáján. A publikált tanulmány az előadás javított, bővített és átdolgozott változata.

PARÁDI József: A magyarországi rendvédelem fejlődési tendenciái 1867-1950. Rendvédelem-történeti Füzetek (Acta Historiae Praesidii Ordinis), XI.évf. (2005) 13.sz. 84-96.p. HU-ISSN 1216-6774. A tanulmány korábbi változata 1998. februárjában Budapesten hangzott el, a Szemere Bertalan Magyar Rendvédelem-történeti Tudományos Társaság Csendőrség-történeti Szakosztálya által szervezett tudományos rendezvénysorozat első szimpozionján. A publikált tanulmány az elöadás javított, bővített és átdolgozott változata.

PARÁDI József: A magyar rendvédelem személyi állományának szociális viszonyai 1867-1945. Rendvédelem-történeti Füzetek (Acta Historiae Praesidii Ordinis), XV.évf. (2008) 17.sz. 57-64.p. HU-ISSN 1216-6774. A tanulmány korábbi változata 2003. november 11-én, Budapesten hangzott el a Szemere Bertalan Magyar Rendvédelem-történeti Tudományos Társaság által szervezett rendvédelemtörténeti tudományos konferencia-sorozatnak a „A rendvédelem humán viszonyai” című XVII. konferenciáján. A publikált tanulmány az előadás javított, bővített és átdolgozott változata.

PARÁDI József A dualizmuskori magyar rendvédelem. Rendvédelem-történeti Füzetek (Acta Historiae Praesidii Ordinis), XVIII.évf. (2010) 21.sz. 66-84.p. HUISSN 1216-6774. A tanulmány korábbi változata 2007. október 5.-én Budapesten hangzott el, a Szemere Bertalan Magyar Rendvédelem-történeti Tudományos Társaság által szervezett magyar rendvédelem-történeti tudományos konferencia-sorozatnak „A rendvédelem fejlödése a XIX-XX. században” címü XXI. konferenciáján. A publikált tanulmány az előadás javított, bővített és átdolgozott változata.

PARÁDI József: A két világháború közötti Magyar Királyság rendvédelme. Rendvédelem-történeti Füzetek (Acta Historiae Praesidii Ordinis), XVIII.évf. (2010) 21.sz. 85-100.p. HU-ISSN 1216-6774. A tanulmány korábbi változata 2007. október 5.-én Budapesten hangzott el a Szemere Bertalan Magyar Rendvédelem-történeti Tudományos Társaság által szervezett rendvédelem-történeti tudományos konferencia-sorozatnak „A magyar rendvédelem fejlödése a $X I X-X X$. században" címü XXI. konferenciáján. A publikált tanulmány az előadás javított, bővített és átdolgozott változata. 
PARÁDI: Rendvédelem - karhatalom 1867-1945.

PARÁDI: A polgári magyar állam rendőrségei 1867-1945. (6.;)

PARÁDI: Az államfő testőrségei az Osztrák-Magyar Monarchiában.

(43.;)

PARÁDI: Rendvédelmi testületek a polgári magyar állam időszakában 1867-1919.

(5.;)

PARÁDI: A katonailag szervezett örtestület és a polgári örtestület. (5.;)

PARÁDI: A magyar rendvédelem 1867-1918.

(3.;)

ZACHAR

$(1 . ;)$

PARÁDI József: Rendvédelem - karhatalom 1867-1945. Rendvédelem-történeti Füzetek (Acta Historiae Praesidii Ordinis), XX.évf. (2011) 23.sz. 111-123.p. HUISSN 1216-6774. A tanulmány korábbi változata 2009. október 9-én Budapesten hangzott el, a Szemere Bertalan Magyar Rendvédelem-történeti Tudományos Társaság által szervezett rendvédelem-történeti tudományos konferenciasorozatnak „A kiegyezéstől az ezredfordulóig felszámolt országos hatáskörü magyar rendvédelmi testületek." címü XXIII. konferenciáján. A publikált tanulmány az előadás javított, bővített és átdolgozott változata.

PARÁDI József: A polgári magyar állam rendőrségei 1867-1945. Rendvédelemtörténeti Füzetek (Acta Historiae Praesidii Ordinis), XX.évf. (2011) 23.sz. 124143.p. HU-ISSN 1216-6774. A tanulmány korábbi változata 2009. október 9.-én Budapesten hangzott el, a Szemere Bertalan Magyar Rendvédelem-történeti Tudományos Társaság által szervezett rendvédelem-történeti tudományos konferencia-sorozatnak „A kiegyezéstől az ezredfordulóig felszámolt országos hatáskörü magyar rendvédelmi testületek." címü XXIII. konferenciáján. A publikált tanulmány az előadás javított, bővített és átdolgozott változata.

PARÁDI József: Az államfö testőrségei az Osztrák-Magyar Monarchiában. Rendvédelem-történeti Füzetek (Acta Historiae Praesidii Ordinis), XXIII.évf. (2013) 27-28-29-30.sz. 155-160.p. HU-ISSN 1216-6774.

PARÁDI József: Rendvédelmi testületek a polgári magyar állam időszakában 1867-1919. Rendvédelem-történeti Füzetek (Acta Historiae Praesidii Ordinis), XXIII.évf. (2013) 31-32-33-34.sz. 121-146.p. HU-ISSN 1216-6774. A tanulmány korábbi változata 2014. február 21-én, Budapesten hangzott el, a Szemere Bertalan Magyar Rendvédelem-történeti Tudományos Társaság által szervezett rendvédelem-történeti tudományos szimpozion-sorozatnak „, A kivételes hatalom és a közbiztonság” címủ XIV. szimpozionján. A publikált tanulmány az előadás javított, bővített és átdolgozott változata.

PARÁDI József: A katonailag szervezett őrtestület és a polgári őrtestület. Rendvédelem-történeti Füzetek (Acta Historiae Praesidii Ordinis), XXV.évf. (2015) 4344-45-46.sz. 77-84.p. HU-ISSN 1216-6774.

PARÁDI József: A magyar rendvédelem 1867-1918. Rendvédelem-történeti Füzetek (Acta Historiae Praesidii Ordinis), XXVII.évf. (2017) 53.sz. 33-52.p. HU-ISSN 1216-6774.

ZACHAR József: Az Osztrák-Magyar Monarchia örökös tartományainak rendvédelmi testületei. Rendvédelem-történeti Füzetek (Acta Historiae Praesidii Ordinis), HU-ISSN 1216-6774. I.évf. (1991) 1.sz. 17-29.p. HU-ISSN 1216-6774. A tanulmány korábbi változata 1990. április 24.-én Budapesten hangzott el a Szemere Bertalan Magyar Rendvédelem-történeti Tudományos Társaság által szervezett rendvédelem-történeti tudományos konferencia-sorozatnak ,A magyar rendvédelmi testületek és az önkormányzati szervek kapcsolata 1848-1945" címü I. konferenciáján. A publikált tanulmány az előadás javított, bővített és átdolgozott változata.

\section{ADATTÁRAK}

BÖLÖNY

$(34 . ; 35 . ;)$

BöLÖNY József: Magyarország kormányai 1848-1975. Budapest, 1978, Akadémia. 328 p. HU-ISBN 963051755 8. /A Magyar Országos Levéltár Kiadványai, IV. - Levéltártan és történeti forrásdokumentumok, 2./ HU-ISSN 0441-4985.

\section{DOKUMENTUMGYÜJTEMÉNYEK}

NÉMETHY — TÖRÖK

\section{ALBUMOK}

VÉCSEY

(18.;19.;22.;33.;51.;56.;63.;64.; 65.;68.;)

\section{JOGSZABÁLYOK}

1870/XLII.tc.

(4.;)

1871/XVIII.tc.

(4.;)

1872/XXXVI.tc.
NÉMETHY Tihamér — TÖRÖK Lajos: Rendöri vonatkozású törvények, rendeletek és eljárási szabályok gyüjteménye. Budapest, 1926, Editor. 822 p. /Rendörtisztviselők zsebkönyvtára./

VÉCSEY Leó (szerk.): A 40 éves budapesti detektív testület jubiláris albuma 1886-1926. Budapest, 1927, A Magyar Királyi Államrendőrség Detektívtestületének Nyugdíjpótló és Segélyező Egyesülete. 320 p.

— 1870/XLII.tc. a köztörvényhatóságok rendezéséröl.

1871/XVIII.tc. a községek rendezéséröl.

1872/XXXVI.tc. Buda-Pest fővárosi törvényhatóság alakításáról és rendezéséröl. 
$1878 /$ V.tc.

(14.;)

1879/XL.tc.

(14.;)

1881/XXI.tc.

(7.;9.;)

1883/I.tc.

(20.;)

1889/XLVI.tc.

(32.;)

1896/XXIII.tc.

(25.;26.;)

1912/LX.tc.

(32.;)

1916/XXXVII.tc.

(50.;)

1916/XXXVIII.tc.

1920/I.tc.

(53.;)

1920/XI.tc.

(59.;)

43 972/1884.BM.r.

(10.;37.;)

9 389/1885. (II. 14.) BM.r.

(38.;)

3 200/1899. (VIII. 15.) IM.r. (25.;)

130 000/1899. (XII. 22.) BM.kr. (27.;)

5 047/1919. (X. 1.) ME.r.

31 300/1920. (V. 1920) BM.r. (55.;)

9 270/1922. (X. 10.) ME.r. (65.;)

18 881/1923. (X. 5.) BM.r. (65.;)
1878/V.tc. a magyar büntetőtörvénykönyv a büntettekről és a vétségekről.

1879/XL.tc. a magyar büntetőtörvénykönyv a kihágásokról.

1881/XXI.tc. a Budapest-fővárosi rendőrségröl.

1883/I.tc. a tisztviselők minősítéséről.

1889/XLVI.tc. a fővárosi rendőrség hatáskörének kiterjesztéséröl Új-Pest és Rákos-Palota községek területére.

— 1896/XXXIII.tc. a bünvádi perrendtartásról.

1912/LX.tc. a Budapest székesfővárosi állami rendőrség hatáskörének Erzsébetfalva, Kispest, Pestszentlörinc községek területére való kiterjesztéséröl.

— 1916/XXXVII.tc. a Fiumei Magyar Királyi Állami Rendőrségről.

— 1916/XXXVIII.tc. a Budapest székesfővárosi m. kir. államrendőrség hatáskörének Csepel község területére való kiterjesztéséről.

1920/I.tc. az alkotmányosság helyreállításáról és az állami főhatalom gyakorlásának ideiglenes rendezéséröl.

— 1920/XI.tc. az állami, államvasúti és vármegyei tisztviselőkre és egyéb alkalmazottakra vonatkozó egyes intézkedésekről.

— 43 972/1884.BM.r. a fôvárosi rendőrség számára kiadott Utasítás tárgyában. NÉMETHY Tihamér - TÖRÖK Lajos: Rendöri vonatkozású törvények, rendeletek és eljárási szabályok gyüjteménye. 26-49.p. Budapest, 1926, Editor. 822 p. /Rendőrtisztviselök zsebkönyvtára./

- $\quad 9389 / 1885$. (II. 14.) BM.r. az új toloncz-szabályzat kibocsátása tárgyában. Magyarországi Rendeletek Tára, XIX.évf. (1885) 1.sz. 164-168.p.

3 200/1899. (VIII. 15.) IM.r. a bünvádi perrendtartásról szóló 1896/XXXIII.tc. életbeléptetése tárgyában.

Igazságügyi Közlöny, VIII.évf. (1899) 8.sz. 229-234.p.

130 000/1899. (XII. 22.) BM.kr. a bűnvádi perrendtartásról szóló 1896/XXXIII.tc. életbe léptetése alkalmából a nyomozó rendőri hatóságok és közegek részére kibocsátott Utasítás tárgyában.

Magyarországi Rendeletek Tára, XXXIII.évf. (1899) II.füzet. 2416-2417.

- $\quad 5$ 047/1919. (X. 1.) ME.r. a rendőrség államosításáról. Magyarországi Rendeletek Tára, LIII.évf. (1919) I.füzet. 752-767.p.

31 300/1920. (V. 1920) BM.r. a Belügyminisztérium kebelében szervezett nyomozó osztály müködéséröl.

Magyarországi Rendeletek Tára, LIV.évf. (1920) I.füzet. 691-692.p.

9 270/1922. (X. 10.) ME.r. a Magyar Királyi Állami Rendőrségnél alkalmazott detektívektől megkívánható elméleti és gyakorlati képzettség megállapítása és az ezzel kapcsolatos intézkedések.

NÉMETHY Tihamér - TÖRÖK Lajos: Rendöri vonatkozású törvények, rendeletek és eljárási szabályok gyüjteménye. 335-339.p. Budapest, 1926, Editor. 822 p. /Rendőrtisztviselök zsebkönyvtára./

18 881/1923. (X. 5.) BM.r. utasítás a detektívtanfolyamra és a detektívvizsgára a detektívfelügyelői tanfolyamra és a detektívfelügyelői vizsgára, valamint a detektívfőfelügyelői minősítő vizsgára vonatkozó 9 207/1922.M.E. rendelet végrehajtására vonatkozóan.

NÉMETHY Tihamér — TÖRÖK Lajos: Rendöri vonatkozású törvények, rendeletek és eljárási szabályok gyüjteménye. 339-355.p. Budapest, 1926, Editor. 822 p. /Rendőrtisztviselök zsebkönyvtára./ 